\title{
Synthesis and Pharmacological Evaluation of a New 2-Azabicyclo[3.3.0]octane Derivative.
}

\author{
Emerson P. Peçanha ${ }^{a}$, Carlos A. M. Fraga ${ }^{a}$, Eliezer J. Barreiro ${ }^{a *}$, Maria F. M. Braga $^{b, c}$, Edna F. R. \\ Pereira and Edson X. Albuquerque
}

${ }^{a}$ Faculdade de Farmácia, Universidade Federal do Rio de Janeiro, CP 68006, 21944-970, Rio de Janeiro - RJ, Brazil

${ }^{\mathrm{b}}$ Department of Pharmacology and Experimental Therapeutics, School of Medicine, University of Maryland, Baltimore, MD 21201, USA

${ }^{\mathrm{c}}$ Departamento de Farmacologia Básica e Clínica, Institiuto de Ciências Biomédicas, Centro de Ciências da Saúde, Universidade Federal do Rio de Janeiro, 21944-970, Rio de Janeiro - RJ, Brazil

\begin{abstract}
No âmbito de uma linha de pesquisas que trata do planejamento, síntese e avaliação farmacológica de novos candidatos a protótipos de agentes neuroativos, descrevemos neste trabalho a síntese e avaliação farmacológica de novo análogo do nebracetam contendo a unidade 2-azabiciclo[3.3.0]octano, planejado como candidato a agente nootrópico útil para o tratamento da doença de Alzheimer. A avaliação das propriedades ao nível dos neurônios do sistema nervoso central utilizando a técnica do "path-clamp" não permitiu evidenciar um perfil de ação central adequado para o novo composto.
\end{abstract}

As part of a research program aiming at the design, synthesis and pharmacological evaluation of a novel lead-candidates of neuroactive compounds, we describe herein the synthesis and the central profile of a new nebracetam analog having a 2-aza-bicyclo[3.3.0]octane system. The new derivative, designed on the basis of the conformational restriction concept, was synthesized in good yields exploring a diastereoselective reductive-amination and cyclization one-pot sequence. The pharmacological profile of this new compound, investigated by using path-clamp techniques on neurons of the CNS, indicated no effects on these cells.

Keywords: 2-azabicyclo[3.3.0]octane derivatives, diastereoselective reductive-amination/ cyclization one-pot process, nebracetam analog

\section{Introduction}

Alzheimer's disease (AD) is the most common cause of dementia among seniors, and it is expected that the number of cases will rise progressively due to increased life expectation ${ }^{1}$. The most promising strategies for the prevention and symptomatic treatment of Alzheimer's disease include the use of antioxidants, cholinergic therapy, estrogen replacement, antinflammatory therapy, in addition to the use of nootropic agents ${ }^{2}$, drugs capable of increasing $\operatorname{cognition}^{3-4}$. The first nootropic agents developed, e.g. piracetam (1), oxiracetam (2) and nebracetam (3), belong to the class of pyrrolidones. These drugs increase cerebral neurotransmission in the dopaminergic, cholinergic, glutamatergic and gabaergic ${ }^{5-6}$ neurotransmissions in the central nervous system $(\mathrm{CNS})^{7}$.

\footnotetext{
* e-mail: eliezer@ufrj.br _ - http://www.farmacia.ufrj.br/lassbio
}

In a research program aimed at developing compounds potentially useful in the treatment of neurodegenerative disorders such $\mathrm{AD}$, we propose the use of the functionalyzed 2-azabicyclo[3.3.0]octane system to obtain $N$-benzyl-2-oxo-5-hydroxymethyl-2-azabicyclo [3.3.0] octane (4), designed as a new analogue of $\mathbf{3}$ (Figure 1). The derivative 4 was rationally planned as a bioisoster ${ }^{8}$ of $\mathbf{3}$, through a conjunctive ring transformation ${ }^{9}$ involving the substitution of the pyrrolidinone ring of $\mathbf{3}$ for the system 3-oxo-2-azabicyclo[3.3.0] octane of 4, as well as the substitution of the aminomethylene group for the hydroxymethylene group (Figure 1). The bicyclic system of $\mathbf{4}$ was introduced to reduce the conformational freedom of the molecule, because such conformational rigidity is likely to favor energetically interactions with endogenous bioreceptors ${ }^{10}$ (Figure 1). As a consequence of the introduction of three carbon atoms, the resulting compound $\mathbf{4}$ became more hydrophobic than the prototype $\mathbf{3}$. Thus, it 
<smiles>NC(=O)CN1CCCC1=O</smiles><smiles>NC(=O)CN1CC(O)CC1=O</smiles><smiles>NCC1CC(=O)N(Cc2ccccc2)C1</smiles>

Figure 1. Structural design of the new bicyclic nebracetam analogue 4.

was expected that $\mathbf{4}$ would cross the blood-brains-barrier more readily than $\mathbf{3}$.

\section{Results and Discussion}

\section{Chemistry}

The synthesis of $\mathbf{4}$ is depicted in Scheme 1. The first stage in obtaining the target compound $\mathbf{4}$ consisted in the regiosselective $\mathrm{C}$-alkylation of 2-carbomethoxycyclopentanone (5), using ethyl bromoacetate and potassium carbonate in acetone at room temperature for $24 \mathrm{~h}^{11}$, to render the diester 6 in $87 \%$ yield. Derivative 6 was then submitted to reductive amination using benzylamonium acetate and sodium cyanoborohydride in methanol under reflux ${ }^{12}$, to furnish as the major product, the desired intermediate compound methyl trans-2- benzylamino- 1 - ethyloxycarbonylmethy - 1 cyclopentanecarboxylate (7a), and its amino isomer methyl cis-2-benzylamino-1-ethyloxycarbonylmethyl-1cyclopentanecarboxylate (7b). From the major isomer 7a, the $\gamma$-lactam 8 was obtained by an in situ cyclization process in $56 \%$ yield after chromatographic purification on silicagel column. In this procedure we were able to isolate $13 \%$ of the trans-cyclopentanamine $\mathbf{7 b}$. Formation of a 4.3:1 ratio between the $\gamma$-lactam $\mathbf{8}$ and the transcyclopentanamine $\mathbf{7 b}$ suggests that the reductive amination step is a diastereoselective process ${ }^{13,14}$. The final step of the synthetic route consisted of the chemoselective reduction of the ester group of $\mathbf{8}$ by employing sodium borohydride in isobutanol under reflux for $2.5 \mathrm{~h}^{15}$, to produce the desired compound 4 in $85 \%$ yield.

Thus, compound 4 was obtained in $41 \%$ overall yield starting from commercial 2-carbomethoxycyclopentanone $\mathbf{5}$.<smiles>COC(OC)C1CCCC1=O</smiles>

5<smiles>CCOC(=O)CC1(C(=O)OCC)CCCC1=O</smiles>

6

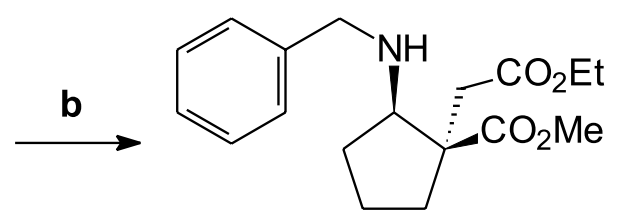

7b

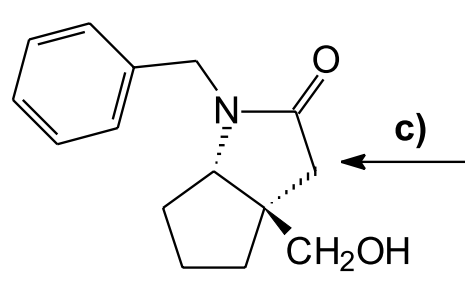

4

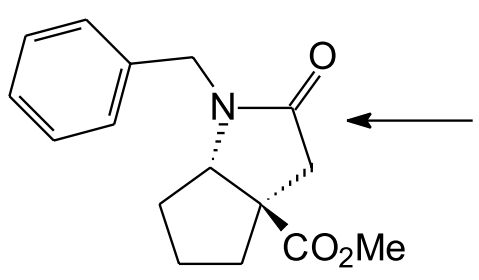

8

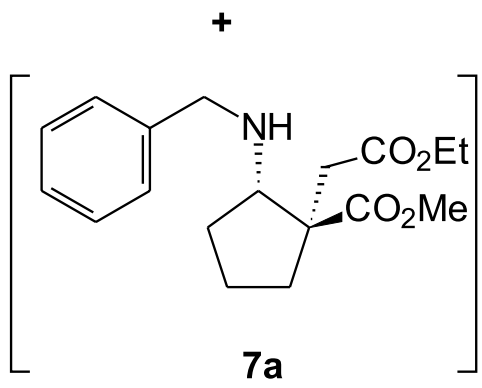

$7 a$

a) $\mathrm{BrCH}_{2} \mathrm{CO}_{2} \mathrm{Et}, \mathrm{K}_{2} \mathrm{CO}_{3}$, acetone, r.t., 24h, $87 \%$; b) $\mathrm{NaBH}_{3} \mathrm{CN}$, benzylamine, $\mathrm{AcOH}$, methanol, reflux, 4h, 56\%; c) $\mathrm{NaBH}_{4}$, isobutanol, reflux, $2 \mathrm{~h}$, $85 \%$.

Scheme 1. Synthesis of the new bicyclic nebracetam analogue 4 . 


\section{Pharmacology}

To investigate whether derivative $\mathbf{4}$ is pharmacologically active, the whole-all mode of the patch-clamp technique was applied to hippocampal neurons, in culture.

Application of a $50 \mu \mathrm{s}, 5 \mathrm{~V}$ pulse via an electroplated bipolar platinum electrode to neurons synaptically connected to the neuron under study always resulted in the activation of a postsynaptic current that was mediated by the evoked release of either glutamate or GABA. Field stimulation-evoked EPSCs and IPSCs could be distinguished from one another on the basis of one of the following criteria: (i) EPSCs were sensitive to blockage by CNQX $\left(10 \mu \mathrm{mol} \mathrm{L} \mathrm{L}^{-1}\right)$ and IPSCs were sensitive to inhibition by picrotoxin (100 $\left.\mu \mathrm{mol} \mathrm{L}^{-1}\right)$; (ii) the decaytime constants of the EPSCs and IPSCs were 12.0 \pm 7.6 and $48.0 \pm 12.7 \mathrm{~ms}$, respectively and (iii) the zero-current potential for EPSCs and IPSCs were $0 \mathrm{mV}$ and $-20 \mathrm{mV}$, respectively. To study the effects of the 2 -azabicyclo [3.3.0] octane derivative 4 on the evoked release of glutamate and GABA, EPSCs and IPSCs were pharmacologically isolated; evoked EPSCs were recorded from neurons that were perfused with picrotoxin (100 $\left.\mu \mathrm{mol} \mathrm{L}^{-1}\right)$ and evoked IPSCs were recorded from neurons that were perfused with CNQX $\left(10 \mu \mathrm{mol} \mathrm{L}^{-1}\right)$.

Following 5-10 min perfusion of the neurons with compound 4 ( 1 and $10 \mu \mathrm{mol} \mathrm{L}^{-1}$ ), there were no changes in the amplitude or kinetics of field-stimulation evoked IPSCs and EPSCs. These results indicate that compound 4 does not alter the tetrodotoxin-sensitive release of GABA and glutamate and does not affect the activity of the postsynaptic GABA $_{A}$ and AMPA receptors underlying the IPSCs and EPSCs, respectively.

\section{Conclusions}

The synthetic route described herein to the new bicyclic analog of nebracetam 4 , structurally planned as a less conformationally free compound than $\mathbf{3}$, represents a useful, efficient and high yield method, exploring a diastereoselective reductive amination-cyclization one-pot reaction sequence as key synthetic step, which also works as a chemical separation process of the diastereomeric cyclopentamine intermediates formed during the reductive amination step of the diester 6. Unfortunately, the pharmacological results presented herein indicated that the new aza-bicyclic compound $\mathbf{4}$, in contrast to nebracetam $3^{5,6,7}$, has no effect on synaptic transmission in the neurons of the CNS, probable due to steric constraints introduced by the presence of the new carbocyclic unit, or due to less pharmacophoric character of the neopentylic hydroxymethane group of $\mathbf{4}$ instead the primary amine of 3. These results are a useful guide to new structural modifications introduced into $\mathbf{4}$ in on-going work.

\section{Experimental Section}

\section{Chemistry}

Melting points were determined with a Quimis 340 apparatus and are uncorrected. ${ }^{1} \mathrm{H}$ NMR spectra were obtained in $\mathrm{CDCl}_{3}$, using tetramethylsilane as an internal standard with a Brucker AC 200 spectrometer. Splitting patterns were as follows: s, singlet; $d$, doublet; $t$, triplet; $q$, quartet. ${ }^{13} \mathrm{C}$ NMR spectra were obtained in the same spectrometer described above at $50 \mathrm{MHz}$, using $\mathrm{CDCl}_{3}$ as internal standard. Infrared spectra were obtained with a Nicolet-505 Magna spectrophotometer using sodium chloride cells. Microanalysis data was obtained using a PerkinElmer 240 analyzer, and a Perkin-Elmer AD-4 balance.

The progress of all reactions was monitored by TLC which was performed on $2.0 \mathrm{~cm}$ x $5.0 \mathrm{~cm}$ aluminum sheets precoated with silica gel 60 (HF-254, Merck) to a thickness of $0.25 \mathrm{~mm}$. The developed chromatograms were visualized under ultraviolet light or iodine revelation. Merck silica gel (70-230 mesh) was used for column chromatography. Solvents used in reactions were dried, redistilled prior to use and stored over 3-4 A molecular sieves.

Methyl 1-(ethyl acetate)-2-oxocyclopentanecarboxylate (6)

Ethyl bromoacetate $(2.53 \mathrm{~g}, 13 \mathrm{mmol})$ was added over a mixture of methyl 2-oxocyclopentanecarboxylate (5) (1.42 $\mathrm{g}, 10 \mathrm{mmol}), \mathrm{K}_{2} \mathrm{CO}_{3}(4.14 \mathrm{~g}, 30 \mathrm{mmol})$ in $10 \mathrm{~mL}$ of acetone. The reaction mixture was stirred at r.t. for $24 \mathrm{~h}$, then $10 \mathrm{~mL}$ of hexane was added and the solution was filtered and concentrated under vacuum. The residue was dissolved in ether $(30 \mathrm{~mL})$ and extracted with $10 \% \mathrm{NaOH}(2 \mathrm{X} 15 \mathrm{~mL})$. The organic layer was submitted to usual work-up and subsequent silica gel flash chromatography purification, furnishing pure $6(1.98 \mathrm{~g}, 87 \%)$ as an yellow oil $\left(\mathrm{R}_{f}=0.49\right.$, $30 \%$ AcOEt/hexane). Anal. Found: C, 58.02; H, 6.98. Calc. for $\mathrm{C}_{11} \mathrm{H}_{16} \mathrm{O}_{5}: \mathrm{C}, 57.89 ; \mathrm{H}, 7.07 \%$. IR $v_{\max } / \mathrm{cm}^{-1} 2980-2850$ (C-H), 1756, 1725 (C=O) (film); ${ }^{1} \mathrm{H} \mathrm{NMR}\left(200 \mathrm{MHz}, \mathrm{CDCl}_{3}\right)$ $\delta 4.12\left(\mathrm{q}, J 7.1 \mathrm{~Hz}, 2 \mathrm{H}, \mathrm{C}_{2} \mathrm{CH}_{3}\right), 3.71\left(\mathrm{~s}, 3 \mathrm{H}, \mathrm{COOC} \underline{H}_{3}\right)$, 2.99 (d, J 17.2 Hz, 1H Cي ${ }_{2} \mathrm{COOCH}_{2} \mathrm{CH}_{3}$ ), 2.80 (d, J 17.2 $\mathrm{Hz}, 1 \mathrm{H} \mathrm{C} \underline{\mathrm{H}}_{2} \mathrm{COOCH}_{2} \mathrm{CH}_{3}$ ), 2.7-1.9 (m, 6H, H-C3, H-C4, H-C5) 1.25 (t, $\left.7.1 \mathrm{~Hz}, 3 \mathrm{H}, \mathrm{CH}_{2} \mathrm{CH}_{3}\right) ;{ }^{13} \mathrm{C} \mathrm{NMR}(50 \mathrm{MHz}$, $\left.\mathrm{CDCl}_{3}\right) \delta 213.7(\mathrm{CO}), 170.6(\underline{\mathrm{COOCH}}), 170.5(\underline{\mathrm{COO}}$ $\left.\mathrm{CH}_{2} \mathrm{CH}_{3}\right), 60.6\left(\mathrm{COOCH}_{2} \mathrm{CH}_{3}\right), 57.3(\mathrm{C} 2), 52.6\left(\mathrm{COOCH}_{3}\right)$, $38.2\left(\mathrm{CH}_{2} \mathrm{COOCH}_{2} \mathrm{CH}_{3}\right), 37.4$ (C5), 33.1 (C3), 19.4 (C4), $13.9\left(\mathrm{COOCH}_{2} \mathrm{CH}_{3}\right)$. 
N-Benzyl-3-oxo-5-carbomethoxy-2-azabicyclo [3.3.0]octane (8)

Sodium cyanoborohydride $(0.41 \mathrm{~g}, 6.5 \mathrm{mmol})$ was added to a solution of $6(1.14 \mathrm{~g}, 5.0 \mathrm{mmol})$, benzylamine $(0.80 \mathrm{~g}$, $7.5 \mathrm{mmol})$ and glacial acetic acid $(0.45 \mathrm{~g}, 7.5 \mathrm{mmol})$ in 100 $\mathrm{mL}$ of methanol. The reaction mixture was stirred under reflux for $4 \mathrm{~h}$ and the solvent was concentrated under vacuum. The residue was dissolved in $3 \mathrm{~mol} \mathrm{~L}^{-1} \mathrm{HCl}(100 \mathrm{~mL})$ and extracted with dichloromethane $(3 \times 100 \mathrm{~mL})$. The organic layer was submitted to usual work-up and subsequent silica gel flash chromatography purification, furnishing pure $8(0.76 \mathrm{~g}, 56 \%)$ as white crystals $\left(\mathrm{R}_{f}=0.19,50 \%\right.$ AcOEt / hexane; mp $89-90^{\circ} \mathrm{C}$ ) and the remaining cyclopentanamine $7 \mathbf{b}(0.17 \mathrm{~g}, 13 \%)$ as a light yellow oil $\left(\mathrm{R}_{f}=0.16,50 \%\right.$ AcOEt $/$ hexane $)$.

8 Anal. Found: C, 71.01; H, 7.10; N, 5.20. Calc. for $\mathrm{C}_{16} \mathrm{H}_{19} \mathrm{NO}_{3}: \mathrm{C}, 70.31 ; \mathrm{H}, 7.01 ; \mathrm{N}, 5.12 \%$. IR $v_{\max } / \mathrm{cm}^{-1} 3080$ (C-H), 2980-2850 (C-H), 1745 (COO), $1684(\mathrm{CON})(\mathrm{KBr})$; ${ }^{1} \mathrm{H}$ NMR $\left(200 \mathrm{MHz}, \mathrm{CDCl}_{3}\right) \delta$ 7.35-7.20 (m, 5H, Ph-H), 4.95 (d, J $\left.15.0 \mathrm{~Hz}, 1 \mathrm{H}, \mathrm{C}_{2}-\mathrm{N}\right), 4.00$ (m, 1H, H-C1), 3.97 (d, J $\left.15.0 \mathrm{~Hz}, 1 \mathrm{H}, \underline{\mathrm{C}}_{2}-\mathrm{N}\right), 3.69$ (s, $\left.3 \mathrm{H}, \mathrm{COOC} \underline{\mathrm{H}}_{3}\right), 3.15(\mathrm{~d}$, $J 17.9 \mathrm{~Hz}, 1 \mathrm{H}, \mathrm{C} 4-\underline{\mathrm{H}}), 2.45$ (d, J $17.9 \mathrm{~Hz}, 1 \mathrm{H}, \mathrm{C} 4-\underline{\mathrm{H}}), 2.25-$ 1.55 (m, 6H, H-C6, H-C7, H-C 8$) ;{ }^{13} \mathrm{C}$ NMR $(50 \mathrm{MHz}$, $\left.\mathrm{CDCl}_{3}\right) \delta 175.4(\underline{\mathrm{CON}}), 172.4\left(\underline{\mathrm{COOCH}}_{3}\right), 135.9$ (Ar-C1), 128.5 (Ar-C2), 127.8 (Ar-C3), 125.4 (Ar-C4), 66.4 (C1), $52.3\left(\mathrm{COO}^{-} \mathrm{H}_{3}\right), 51.6(\mathrm{C} 5), 44.9\left(\mathrm{~N}-\underline{\mathrm{CH}}_{2}\right), 41.4(\mathrm{C} 4), 38.2$ (C6), 30.7 (C8), 24.0 (C7).

7b Anal. Found: C, 67.91; H, 7.98; N, 4.35. Calc. for $\mathrm{C}_{18} \mathrm{H}_{25} \mathrm{NO}_{4}$ : C, 67.69; H, 7.89; N, 4.39\%. IR $v_{\text {max }} / \mathrm{cm}^{-1} 3326$ $(\mathrm{N}-\mathrm{H}), 3086(\mathrm{C}-\mathrm{H}), 2980-2850(\mathrm{C}-\mathrm{H}), 1756(\mathrm{C}=\mathrm{O})(\mathrm{film})$; ${ }^{1} \mathrm{H}$ NMR (200 MHz, $\left.\mathrm{CDCl}_{3}\right) \delta 7.12$ (m, 5H, Ph- $\left.\underline{\mathrm{H}}\right) ; 4.15$ (q, J 7.0 Hz, 2H, $\left.\underline{\mathrm{C}}_{2} \mathrm{CH}_{3}\right), 3.92\left(\mathrm{~d}, J 13 \mathrm{~Hz}, 1 \mathrm{H}, \mathrm{C}_{2}-\mathrm{N}\right)$, $3.81\left(\mathrm{~d}, J 13 \mathrm{~Hz}, 1 \mathrm{H}, \mathrm{C}_{2}-\mathrm{N}\right), 3.70\left(\mathrm{~s}, 3 \mathrm{H}, \mathrm{COOC}_{3}\right), 3.43$ (m, 1H, C1- $\underline{\mathrm{H}}) 2.97\left(\mathrm{~d}, J 17.2 \mathrm{~Hz}, 1 \mathrm{H} \mathrm{C} \underline{\mathrm{H}}_{2} \mathrm{COOCH}_{2} \mathrm{CH}_{3}\right)$, $2.82\left(\mathrm{~d}, J 17.2 \mathrm{~Hz}, 1 \mathrm{H} \mathrm{C}_{2} \mathrm{COOCH}_{2} \mathrm{CH}_{3}\right), 2.7-1.9(\mathrm{~m}, 6 \mathrm{H}$, H-C3, H-C4, H-C5) 1.25 (t, 7.0 Hz, 3H, $\mathrm{CH}_{2} \mathrm{CH}_{3}$ ).

$N$-Benzyl-2-oxo-5-hydroxymethyl-2-azabicyclo [3.3.0]octane (4)

Methanol $(2 \mathrm{~mL})$ was added dropwise for a $30 \mathrm{~min}$ period over a mixture of $1.0 \mathrm{~g}(3.6 \mathrm{mmol})$ of the lactam 8 in the presence of sodium borohydride $(0.35 \mathrm{mg}, 9.2 \mathrm{mmol})$ in $15 \mathrm{~mL}$ of isobutanol. The reaction mixture was maintained under stirring at reflux temperature for $2 \mathrm{~h}$ period, cooled to r.t. and then $70 \mathrm{~mL}$ of aqueous $\mathrm{NH}_{4} \mathrm{Cl}$ and $100 \mathrm{~mL}$ of chloroform were added. The organic layer was submitted to usual work-up and subsequent silica gel flash chromatography purification, furnishing pure $\mathbf{4}(0.72$ $\mathrm{g}, 85 \%)$ as white crystals $\left(\mathrm{R}_{f}=0.12,5 \% \mathrm{MeOH} / \mathrm{CH}_{2} \mathrm{Cl}_{2}\right.$ mp 69-70 ${ }^{\circ} \mathrm{C}$ ). Anal. Found: C, 73.12; H, 7.89; N, 5.55. Calc. for $\mathrm{C}_{15} \mathrm{H}_{19} \mathrm{NO}_{2}: \mathrm{C}, 73.44 ; \mathrm{H}, 7.81 ; \mathrm{N}, 5.71 \%$. IR $v_{\max }$ ' $\mathrm{cm}^{-1} 3340$ (O-H), 3080 (C-H), 2980-2850 (C-H), 1684 $(\mathrm{CON})(\mathrm{KBr}) ;{ }^{1} \mathrm{H}$ NMR $\left(200 \mathrm{MHz}, \mathrm{CDCl}_{3}\right) \delta$ 7.40-7.20 (m, 5H, Ph-H), $4.92\left(\mathrm{~d}, J 15.0 \mathrm{~Hz}, 1 \mathrm{H}, \mathrm{C}_{2}-\mathrm{N}\right), 3.97$ (d, $J$ $\left.15.0 \mathrm{~Hz}, 1 \mathrm{H}, \mathrm{C}_{2}-\mathrm{N}\right), 3.65(\mathrm{~m}, 1 \mathrm{H}, \mathrm{H}-\mathrm{C} 1), 3.51$ (d, J 10.7 $\left.\mathrm{Hz}, 1 \mathrm{H}, \mathrm{C} 5-\mathrm{C}_{2} \mathrm{OH}\right), 3.41\left(\mathrm{~d}, J 10.7 \mathrm{~Hz}, 1 \mathrm{H}, \mathrm{C} 5-\mathrm{C}_{2} \mathrm{OH}\right)$, 2.70 (d, J $17.8 \mathrm{~Hz}, 1 \mathrm{H}, \mathrm{C} 4-\underline{\mathrm{H}}), 2.65$ (br, $\left.1 \mathrm{H}, \mathrm{CH}_{2} \mathrm{O} \underline{\mathrm{H}}\right), 2.31$ (d, J $17.89 \mathrm{~Hz}, 1 \mathrm{H}, \mathrm{C} 4-\underline{\mathrm{H}}), 1.83-1.55$ (m, 6H, H-C6, H$\mathrm{C} 7, \mathrm{H}-\mathrm{C} 8) ;{ }^{13} \mathrm{C}$ NMR (50 MHz, $\left.\mathrm{CDCl}_{3}\right) \delta 174.3$ ( $\underline{\mathrm{CON}}$ ), 136.3 (Ar-C1), 128.5 (Ar-C2), 127.8 (Ar-C3), 127.3 (Ar$\mathrm{C} 4), 67.7$ (C1), 65.3 (C5- $\left.\mathrm{CH}_{2} \mathrm{OH}\right), 47.9$ (C5), $45.0\left(\mathrm{~N}_{-} \mathrm{CH}_{2}\right)$, 41.1 (C4), 36.6 (C6), 30.7 (C8), 23.8 (C7).

\section{Pharmacology}

Cultures of hippocampal neurons were prepared by a procedure similar to that published elsewhere ${ }^{16}$. Neurons cultured for 10 to 30 days were used in this study.

Postsynaptic currents were recorded from cultures of hippocampal neurons according to the standard patchclamp technique ${ }^{17}$ through an LM-EPC-7 amplifier (List Electronics, Heidelberg, Germany). The signals were filtered at $3 \mathrm{~Hz}$, stored on VCR tapes, digitalized at $50 \mathrm{~ms}$ and analyzed on an IBM-compatible microcomputer. A specially designed bipolar electrode was used to stimulate a neuron synaptically connected to the neuron under study. The bath solution used to perfuse the neurons at a rate of 2-4 $\mathrm{mL} \mathrm{min}^{-1}$ had the following composition (in $\mathrm{mmol} \mathrm{L}^{-1}$ ): $\mathrm{NaCl}, 165 ; \mathrm{KCl}, 5 ; \mathrm{CaCl}_{2}, 2$; glucose, 10; and $\mathrm{N}$-[2hydroxyethyl]piperazine- $\mathrm{N}$-[2-ethane sulfonic acid] (HEPES), 5 ( $\mathrm{pH}=7.3$ adjusted with $\mathrm{NaOH} ; 340$ mOsm). The solution used to fill the path pipettes had the following composition (in mmol L-1): $\mathrm{CsCl}, 160$; Cs-ethylene-glycol $\operatorname{bis}(\beta$-amino-ethyl ether)-N,N'-tetraacetic acid, 10 ; and HEPES, 10 (pH = 7.3 adjusted with $\mathrm{CsOH} ; 340$ mOsm). The patch microelectrodes were pulled from borosilicate capillary glass (World Precision Instruments, New Haven, CT) and when filled with the pipette solution had resistances in the range of 2-5 M $\Omega$. All the experiments were performed at room temperature $\left(22-25{ }^{\circ} \mathrm{C}\right)$. The test solutions were applied to the surface of the hippocampal neurons through an array of parallel glass tubes ( $400-\mu$ m i.d.) glued together and assembled on a Narishige micromanipulator. The time constant for solution exchange was $20 \mathrm{~ms}$. These tubes were positioned at about 50-100 $\mathrm{mm}$ away from the neuron under study. Each tube was connected to a reservoir filled with the test solution and gravity fed at a rate of $1.2 \mathrm{~mL}$ $\min ^{-1}$. A computer-controlled stepping motor was used to move the barrels, so that a single neuron could be exposed to different test solutions. 
Drugs and toxins. 6-Cyano-7-nitroquinoxaline-2,3dione (CNQX) was obtained from Research Biochemical International (Natick, MA). Picrotoxin was purchased from Sigma Chemical Co (St. Louis, MO) All chemicals were dissolved in double-distilled water, and the stock solutions (0.01-1 mol L-1) were kept frozen until ready to use. $\mathrm{NaOH}$ was used to dissolve CNQX (the $10 \mathrm{mmol} \mathrm{L}^{-1}$ stock of CNQX had $12.2 \mathrm{mmol} \mathrm{L}^{-1} \mathrm{NaOH}$ ).

Data analysis. The peak amplitude, 10-90\% rise time, and decay-time constants of the postsynaptic currents were analyzed using the pCLAMP program (Axon Instruments, CA).

\section{Acknowledgments}

We are grateful to Pronex (grant FINEP \#0888), FUJB and FAPERJ (Brazil) for financial support of this work and to $\mathrm{CNPq}$ (Brazil) for fellowships (EPP, CAMF and EJB).

\section{References}

1. Morris, J.C. J. Clin. Invest. 1999, 104, 1171.

2. Yamada, K.; Ren, X.; Nabeshima, T. Jpn. J. Pharmacol. 1999, 80, 9.

3. Mondadori, C. Crit. Rev. Neurobiol. 1996, 10, 357.

4. Loscertales, M.; Rose, S.P.; Daisley, J.N.; Sandi, C. Eur. J. Neurosci. 1998, 10, 2238.

5. Takeo, S.; Hayashi, H.; Tadokoro, M.; Takagi, K.; Miyake, K.; Takagi, N.; Oshikawa, S. Biol. Pharm. Bull. 1997, 20, 360.
6. Takeo, S.; Hayashi, H.; Miyake, K.; Takagi, K.; Tadokoro, M.; Takagi, N.; Oshikawa, S. Br. J. Pharmacol. 1997, 121, 477.

7. Nishizaki, T.; Matsuoka, T.; Nomura, T.; Sumikawa, K.; Shiotani, T.; Watabe, S.; Yoshii, M. Mol. Pharmacol. 1998, 53, 1.

8. Patani, G. A.; LaVoie E. I. Chem. Rev. 1996, 96, 3147.

9. Wermuth, C.G. In The Practice of Medicinal Chemistry; Wermuth, C.G., Ed.; Academic Press; London, 1996, pp. 240-243.

10. Gilli, P.; Ferreti, V.; Gilli, G.; Borea, P.A. J. Phys. Chem. 1994, 98, 1515.

11. Barco, A.; Benneti, S.; Pollini, G.P. Synthesis 1973, 316.

12. Banwell, M.G.; Bui, C.T.; Pham, H.T.T.; Simpson, G.W. J. Chem. Soc., Perkin Trans 1 1996, 967.

13. Fraga, C. A. M.; Barreiro, E. J. Synth. Commun. 1995, $25,1133$.

14. Teixeira, L. H. P.; Barreiro, E. J.; Fraga, C. A. M. Synth. Commun. 1997, 27, 3241.

15. Soai, K., Oyamada, H., Okawa, A. Synth. Commun. 1982, 12, 463.

16. Alkondon, M.; Albuquerque, E. X. J. Pharmacol. Exp. Ther. 1993, 265, 1455.

17. Hamill, O. P.; Marty, A.; Neher, E.; Sakmann, B.; Sigworth, F. J. Pfluegers Arch. 1981, 391, 85.

Received: November 14, 2000 Published on the web: May 16, 2001 